\title{
HOLDER DESIGN EVALUATION OF GAMMA AREA MONITOR IN SOLID RADIOACTIVE WASTE INTERM STORAGE ROOM OF RADIOMETALURGY INSTALLATION
}

\section{EVALUASI DESAIN HOLDER DETEKTOR RADIASI GAMMA PADA PERANGKAT GAMMA AREA MONITOR DI RUANG PENYIMPANAN LIMBAH SEMENTARA INSTALASI RADIOMETALURGI}

\author{
Waringin Margi Yusmaman ${ }^{1}$, Mohamad Sukron Fajrin Husein ${ }^{1}$, Denia Karlina Utami Putri ${ }^{1}$, Kesi \\ Indriana ${ }^{1}$ \\ ${ }^{1}$ Pusat Teknologi Bahan Bakar Nuklir, BATAN \\ Email:wmyus@batan.go.id
}

Diterima : 31 Agustus 2020 , diperbaiki : 19 Oktober 2020 , disetujui : 24 Oktober 2020

\begin{abstract}
HOLDER DESIGN EVALUATION OF GAMMA AREA MONITOR IN SOLID RADIOACTIVE WASTE TEMPORARY STORAGE ROOM OF RADIOMETALURGY INSTALLATION. Radiometalurgy Installation (RMI) is one of Non-Reactor Nuclear Installation where postirradiation examination (PIE) takes place, which gives gamma radiation ranged from one $\mu \mathrm{Sv} / \mathrm{h}$ to the order of $\mathrm{mSv} / \mathrm{h}$. The PIE activity produces high-activity radioactive waste as a by-product that stored temporarily in RMI Building before it is transported to PTLR. The temporary solid radioactive waste storage room is equipped with in situ gamma area monitor (GAM) as external radiation protection for radioactive waste operator. This research is conducted to understand the gamma radiation capture characteristic of GAM detector and evaluate the position of detector, the design of detector holder, and the threshold setting of radiation detection alarm in The temporary solid radioactive waste storage room. The research is conducted by measuring a standard radiation source Cs-137 with the activity of $1 \mu \mathrm{Ci}$ using GAM Detector with variant of position in 4 point, which are in the middle-front of detector, the front-side of the detector vessel, the middle of detector vessel, and back-end of detector vessel, along with variation of source to detector distance, which are $0 \mathrm{~cm}, 10 \mathrm{~cm}, 20 \mathrm{~cm}, 30 \mathrm{~cm}, 40 \mathrm{~cm}$, and $50 \mathrm{~cm}$. The measurement of the dose rate is carried out from the direction of solid radioactive waste that is placed as a radiation source (one direction). The measurement done in the middle-front of the detector gives the highest dose of gamma radiation measured which are 5.63, 4.20, $0.58,0.28(\mu \mathrm{Sv} / \mathrm{h})$. The result of gamma radiation dose measurement by the detector shows that the closer the source to middle-front part of the detector the higher the radiation measured. The holder design of the gamma radiation detector used in the current GAM device provides information on the gamma radiation dose rate of $74.26 \%$ of the actual dose rate. Currently, the position of the middle-front side of the detector holder is upward. Therefore the design of detector holder needs to be modified in order for the detector to measures the dose more effectively and give the true number of dose measured.
\end{abstract}

Keywords: Gamma Radiation Detector, Gamma Area Monitor, Dose Rate, Radiation

\section{ABSTRAK}

EVALUASI DESAIN HOLDER DETEKTOR PERANGKAT GAMMA AREA MONITOR DI RUANG PENYIMPANAN SEMENTARA LIMBAH RADIOAKTIF PADAT INSTALASI RADIOMETALURGI. Instalasi Radiometalurgi (IRM) sebagai salah satu Instalasi Nuklir Non Reaktor (INNR) melakukan uji metalurgi terhadap bahan bakar nuklir pasca iradiasi yang mempunyai laju dosis radiasi gamma dengan orde satuan di atas mikro sievert per jam. Kegiatan 
pengujian radiometalurgi menghasilkan limbah radioaktif padat radiasi tinggi yang selanjutnya disimpan di ruang penyimpanan sementara limbah radioaktif padat IRM. Ruang penyimpanan sementara limbah radioaktif padat dilengkapi perangkat pemantauan radiasi gamma secara in situ untuk memantau radiasi gamma ruangan dalam rangka memproteksi pekerja radiasi terhadap radiasi eksterna. Penelitian ini bertujuan untuk mengetahui karakteristik tangkapan radiasi gamma oleh detektor, evaluasi posisi, desain holder detektor dan setting batasan keselamatan perangkat Gamma Area Monitor (GAM) di ruang penyimpanan sementara limbah radioaktif padat. Kegiatan penelitian dilakukan dengan cara mengukur radiasi gamma yang berasal dari sumber standar pemancar gamma cesium 137 dengan aktivitas $1 \mu$ Ci menggunakan detektor pada perangkat GAM dengan posisi menjulang ke atas. Pengukuran radiasi gamma dilakukan pada 4 titik yang berbeda yaitu pada ujung depan detektor, bagian depan dinding detektor, bagian tengah dinding detektor dan bagian pangkal dinding detektor. Parameter jarak antara sumber radiasi dengan detektor pada jarak $0 \mathrm{~cm}, 10 \mathrm{~cm}, 20 \mathrm{~cm}, 30 \mathrm{~cm}, 40 \mathrm{~cm}$ dan $50 \mathrm{~cm}$. Pengukuran dilakukan dari satu arah limbah radioaktif padat diletakkan sebagai sumber radiasi. Hasil pembacaan laju dosis radiasi gamma oleh detektor menunjukkan bahwa semakin mendekati ujung depan detektor, laju dosis radiasi terbaca lebih efektif. Pada titik ujung depan memberikan pembacaan laju dosis radiasi yang paling tinggi (5.63, 4.20, 0.58, 0.28 ( $\mu$ Sv/jam)). Data menyimpulkan bahwa karakterisitik window pembacaan detektor terhadap radiasi gamma terletak pada ujung depan detektor. Saat ini, posisi ujung depan detektor menghadap ke atas, sehingga memberikan informasi laju dosis radiasi gamma senilai $74.26 \%$ dari laju dosis yang sebenarnya. Dengan melihat posisi dan desain holder pada saat ini diperlukan penyesuaian posisi, desain holder detektor dan setting batas keselamatan pada GAM.

Kata kunci : detektor gamma, Gamma Area Monitor, laju dosis, radiasi.

\section{INTRODUCTION}<smiles>C1CC2CC12</smiles>
adiometalurgy Installation (RMI) as one of non-reactor nuclear installation (INNR) in Indonesia is equipped with material and spent fuel testing laboratory to conduct research and development in Radio-metallurgical analysis, Physical-chemisty analysis, and Post Irradiation Examination for nuclear fuel in research reactor and power reactor. The operation of RMI produce radioactive waste ranged from low to high level of radioactivity. Radioactive waste is a radiation source or materials that become radioactive or contaminated with radioactive source due to the operation of nuclear installation and cannot be utilized anymore ${ }^{[1][2]}$. RMI produce radioactive waste in forms of solid, liquid, and aerosol. The radioactive waste mainly radiates gamma radiation while alpha and beta emitter also presents ${ }^{[3]}$. The radioactive waste comes from the use of radioactive material in $\mathrm{RMI}$ and fission product that contained in the spent nuclear fuel that undergone $\mathrm{PIE}^{[3]}$. Waste management must be done by waste producer and implementing agent (BATAN) to overcome potential of external and internal radiation hazard. Internal radiation hazard came from a radioactive source that goes inside a human or radiation worker ${ }^{[4]}$. The internal radiation hazard can cause higher damage when alpha emitter is presents inside a human body ${ }^{[5]}$. The external radiation hazard present from the radiation source located outside the human body or in work environment. The greater external radiation hazard is usually caused by high activity gamma emitter or beta emitter that can also produce $x$-ray trough bremsstrahlung interaction ${ }^{[6]}$. Solid waste in interm storage room (Figure 1) of radiometalurgy installation comes from Post Irradiation Examination (PIE) done in RMI. PIE is an activity of analysing the chemical and physical properties of nuclear fuel and its structure after 
irradiation from nuclear reactor ${ }^{[7]}$. The solid radioactive waste consisted of mechanical parts of the hotcell used to conduct PIE and other apparatus used in laboratory where PIE sample is analysed such as gloves or lab sheets. The fission product that often presents as radioactive waste in RMl are the alpha, beta, and gamma emitter with high activity that give high external radiation hazard ${ }^{[8]}$, which can harm the radioactive waste officer.

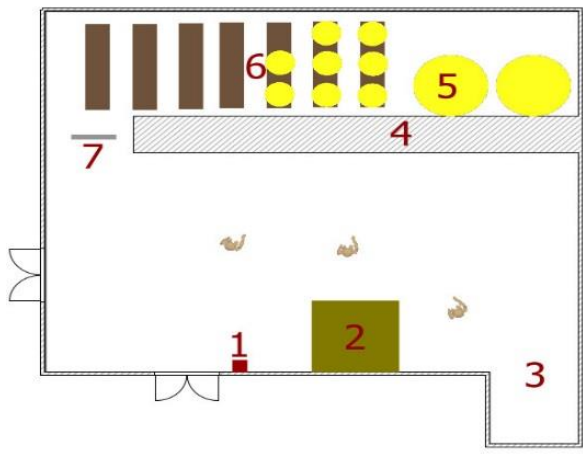

1. GAM device

2. Solid radioactive waste compactor

3. Uncompacted waste

4. Concrete bricks shild

5. Concrete shell drum

6. Solid radioactive waste store

7. Portable $\mathrm{Pb}$ shield

Figure 1. Scheme of Interm storage solid radioactive waste in $\mathrm{RMI}$

The storage room for solid radioactive waste is equipped with GAM. The purpose of GAM is to measure the dose rate of gamma radiation in the temporary solid radioactive waste storage room to determining radiation protection method for radioactive waste office. The unit of GAM is installed in the north wall inside temporary solid radioactive waste storage room, which are the radioactive waste handling area. The detector of GAM is positioned upward so the centre of detector is facing the roof while the threshold setting for the detector alarm is $10 \mu \mathrm{Sv} / \mathrm{h}$.

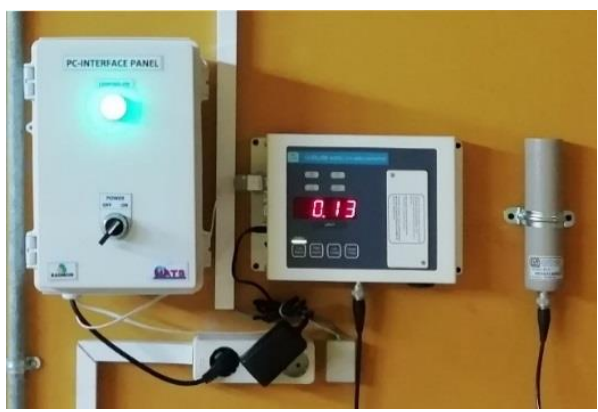

Figure 2. The Gamma Area Monitor Unit Installed in Solid Radioactive Waste Temporary Storage Room

Figure 2 show GAM unit installed in the temporary solid radioactive waste storage room. The radiation measurement in gamma detector is affected by the source to detector position ${ }^{[9][10]}$. The efficiency of activity measurement in gamma spectrometry system is affected by geometry parameter in the detector system and source position ${ }^{[11]}$. The position of GAM detector and the threshold setting of the alarm need to be evaluated to prove the effectiveness of dose measurement and provide a safe work environment for the radioactive waste officer. The evaluation of position and alarm threshold can also contribute to improve the performance of GAM installed in the other room of RMI.

The detector of GAM is installed facing upwards as seen in Figure 2, therefore the radiation dose rate measured by the unit is not the actual dose rate received by the worker in the temporary solid radioactive waste storage room, and this is the current hypothesis. This paper is in the evaluation and analysis stage. The research is conducted to understand the gamma radiation capture characteristic of GAM detector 
and evaluate the position of detector, the design of detector holder, and the threshold setting of radiation detection alarm in the temporary solid radioactive waste storage room by measuring radiation dose emitted from CS-137 standard source with activity of $1 \mu \mathrm{Ci}$ in various position.

\section{METODOLOGY}

The research is conducted by measuring Cs-137 standard source in various position and source-to-detector (STD) distance. The radiation measurement is done in 4 positions, which are in the middle-front of detector, the front-side of the detector vessel, the middle of detector vessel, and back-end of detector vessel. Figure 3 shows the 4 measurement positions with the horizontal source to the surface. The various STD distances are $0 \mathrm{~cm}, 10 \mathrm{~cm}, 20 \mathrm{~cm}, 30 \mathrm{~cm}$, $40 \mathrm{~cm}$ and $50 \mathrm{~cm}$ and conducted in all 4 measurement positions.

The standard radiation source of Cs-137 with activity of $1 \mu \mathrm{Ci}$ in April 2011 $(0.813 \mu \mathrm{Ci}$ at April 2020) is placed according to the position of measurement and STD distance. The radiation measurement is conducted 3 times for each variation and the result is compared with the dose rate measured with RadEye PRD00002 radiation surveymeter. The dose rate measurement will be used to determine the gamm radiatio capture characteristic of GAM detector and evaluate the position of the detector.

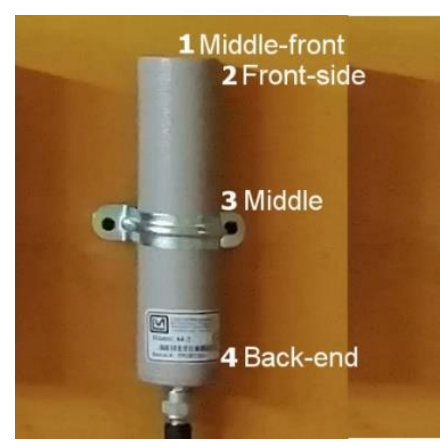

Figure 3. The GAM Detector and Source Position for Radiation Measurement

\section{RESULT AND DISCUSSION}

The result of dose rate measurement in each positions is in line with the theory of distance to radiation measurement. The dose rate measured is inversely related to square distance. The 4 positions of radiation measurement can be divided into 2 groups, which are the detector-end group (position 1 and 2) and the detector vessel group (position 3 and 4). Table 1 shows the measurement result in each position and distances. The measurement in position 1 and 2 from distance $50 \mathrm{~cm}$ to $20 \mathrm{~cm}$ does not show significance difference, which has the result of $0.123-0.230 \mu \mathrm{Sv} / \mathrm{h}$. The same measurement done in distance of $10 \mathrm{~cm}$ show significance difference with the number of $0.360-0.403 \mu \mathrm{Sv} / \mathrm{h}$, the difference becomes more visible in the distance of $0 \mathrm{~cm}$ with the dose rate acquired are 5.633 and $4.183 \mu \mathrm{Sv} / \mathrm{h}$ for position 1 and 2 respectively. A very visible difference can be seen in Figure 4 (a) and 4 (b) where the measurement was done in the distance of $0 \mathrm{~cm}$ at position 1 and position 2. The use of $1 \mu \mathrm{Ci}$ source (base activity in 2011 Cs-137 $\left(T_{1 / 2}=\right.$ $30.07 y$ )) has given insignificance dose rate measurement result done at STD distance of $30 \mathrm{~cm}$, it is due to the low 
activity of the radiation source. The low activity of radiation source also provides understanding the gamma radiation

captures characteristic of the detector that

\begin{tabular}{|c|c|c|c|c|c|}
\hline $\begin{array}{l}\text { Distance } \\
\text { (cm) }\end{array}$ & \multicolumn{3}{|c|}{ Dose Rate $(\mu \mathrm{Sv} / \mathrm{h})$} & $\begin{array}{c}\text { Average Dose } \\
\text { Rate }(\mu \mathrm{Sv} / \mathrm{h})\end{array}$ & $\begin{array}{l}\text { Dose Rate by RadEye } \\
\text { Surveymeter ( } \mu \text { Sv/jam) }\end{array}$ \\
\hline \multicolumn{6}{|c|}{ Position 1} \\
\hline 50 & 0.120 & 0.140 & 0.140 & 0.133 & 0.040 \\
\hline 40 & 0.140 & 0.150 & 0.150 & 0.147 & 0.050 \\
\hline 30 & 0.160 & 0.210 & 0.210 & 0.193 & 0.060 \\
\hline 20 & 0.210 & 0.230 & 0.250 & 0.230 & 0.100 \\
\hline 10 & 0.370 & 0.410 & 0.430 & 0.403 & 0.210 \\
\hline 0 & 5.500 & 5.600 & 5.800 & 5.633 & 4.870 \\
\hline \multicolumn{6}{|c|}{ Position 2} \\
\hline 50 & 0.130 & 0.120 & 0.120 & 0.123 & 0.040 \\
\hline 40 & 0.150 & 0.160 & 0.160 & 0.157 & 0.050 \\
\hline 30 & 0.160 & 0.190 & 0.190 & 0.180 & 0.060 \\
\hline 20 & 0.180 & 0.220 & 0.220 & 0.207 & 0.100 \\
\hline 10 & 0.340 & 0.370 & 0.370 & 0.360 & 0.210 \\
\hline 0 & 4.150 & 4.200 & 4.200 & 4.183 & 4.870 \\
\hline \multicolumn{6}{|c|}{ Position 3} \\
\hline 50 & 0.140 & 0.130 & 0.130 & 0.133 & 0.040 \\
\hline 40 & 0.140 & 0.160 & 0.170 & 0.157 & 0.050 \\
\hline 30 & 0.160 & 0.170 & 0.170 & 0.167 & 0.060 \\
\hline 20 & 0.180 & 0.190 & 0.220 & 0.197 & 0.100 \\
\hline 10 & 0.270 & 0.280 & 0.290 & 0.280 & 0.210 \\
\hline 0 & 0.570 & 0.580 & 0.580 & 0.577 & 4.870 \\
\hline \multicolumn{6}{|c|}{ Position 4} \\
\hline 50 & 0.140 & 0.130 & 0.130 & 0.133 & 0.040 \\
\hline 40 & 0.140 & 0.130 & 0.120 & 0.130 & 0.050 \\
\hline 30 & 0.160 & 0.180 & 0.190 & 0.177 & 0.060 \\
\hline 20 & 0.180 & 0.200 & 0.210 & 0.197 & 0.100 \\
\hline 10 & 0.210 & 0.220 & 0.230 & 0.220 & 0.210 \\
\hline 0 & 0.260 & 0.250 & 0.280 & 0.263 & 4.870 \\
\hline
\end{tabular}

the dose rate measured will give higher end. result when conduct near the detector-

\section{Table 1. Dose Rate Measurement Using GAM Detector in Each Measurement \\ Position}




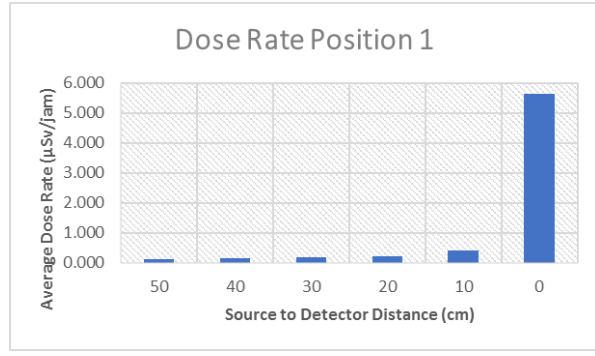

(a)

Dose Rate Position 3

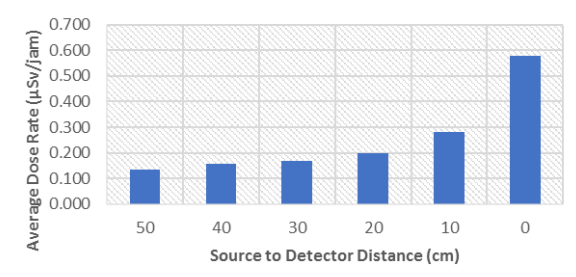

(c)

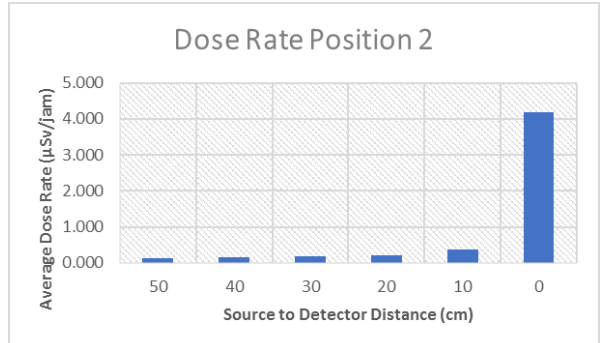

(b)

\section{Dose Rate Position 4}

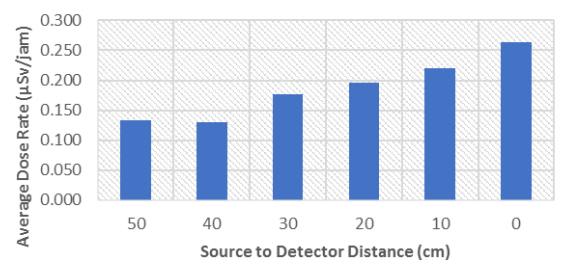

(d)

Figure 4. Dose Rate Measurement in position 1 (a), position 2 (b), position 3 (c) and position 4 (d)

Table 2 shows the measurement data sorted in the same distance for each position respectively. Figure 5 shows the

comparison of dose measurement in each position for the same distance.

Table 2. Radiation Dose Rate Measurement with Gamma Area Monitor Detector for each STD Distance

\begin{tabular}{|c|c|c|c|c|}
\hline Position & \multicolumn{3}{|c|}{ Dose Rate $(\mu \mathrm{Sv} / \mathrm{h})$} & Average Dose Rate $(\mu \mathrm{Sv} / \mathrm{h})$ \\
\hline \multicolumn{5}{|c|}{ STD Distance $50 \mathrm{~cm}$} \\
\hline 1 & 0.120 & 0.140 & 0.140 & 0.133 \\
\hline 2 & 0.130 & 0.120 & 0.120 & 0.123 \\
\hline 3 & 0.140 & 0.130 & 0.130 & 0.133 \\
\hline 4 & 0.140 & 0.130 & 0.130 & 0.133 \\
\hline \multicolumn{5}{|c|}{ STD Distance $40 \mathrm{~cm}$} \\
\hline 1 & 0.140 & 0.150 & 0.150 & 0.147 \\
\hline 2 & 0.150 & 0.160 & 0.160 & 0.157 \\
\hline 3 & 0.140 & 0.160 & 0.170 & 0.157 \\
\hline 4 & 0.140 & 0.130 & 0.120 & 0.130 \\
\hline \multicolumn{5}{|c|}{ STD Distance $30 \mathrm{~cm}$} \\
\hline 1 & 0.160 & 0.210 & 0.210 & 0.193 \\
\hline 2 & 0.160 & 0.190 & 0.190 & 0.180 \\
\hline 3 & 0.160 & 0.170 & 0.170 & 0.167 \\
\hline 4 & 0.160 & 0.180 & 0.190 & 0.177 \\
\hline
\end{tabular}


Holder Design Evaluation of Gamma Area Monitor In

Radiometalurgy Installation

(Waringin Margi Yusmaman, dkk)

\begin{tabular}{|c|c|c|c|c|}
\hline Position & \multicolumn{3}{|c|}{ Dose Rate $(\mu \mathrm{Sv} / \mathrm{h})$} & Average Dose Rate $(\mu \mathrm{Sv} / \mathrm{h})$ \\
\hline 1 & 0.210 & 0.230 & 0.250 & 0.230 \\
\hline 2 & 0.180 & 0.220 & 0.220 & 0.207 \\
\hline 3 & 0.180 & 0.190 & 0.220 & 0.197 \\
\hline 4 & 0.180 & 0.200 & 0.210 & 0.197 \\
\hline \multicolumn{5}{|c|}{ STD Distance $10 \mathrm{~cm}$} \\
\hline 1 & 0.370 & 0.410 & 0.430 & 0.403 \\
\hline 2 & 0.340 & 0.370 & 0.370 & 0.360 \\
\hline 3 & 0.270 & 0.280 & 0.290 & 0.280 \\
\hline 4 & 0.210 & 0.220 & 0.230 & 0.220 \\
\hline \multicolumn{5}{|c|}{ STD Distance $0 \mathrm{~cm}$} \\
\hline 1 & 5.500 & 5.600 & 5.800 & 5.633 \\
\hline 2 & 4.150 & 4.200 & 4.200 & 4.183 \\
\hline 3 & 0.570 & 0.580 & 0.580 & 0.577 \\
\hline 4 & 0.260 & 0.250 & 0.280 & 0.263 \\
\hline
\end{tabular}

Jarak detektor dan sumber $(50 \mathrm{~cm})$

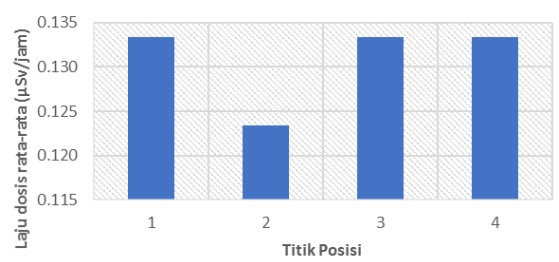

(a)

Jarak detektor dan sumber $(30 \mathrm{~cm})$

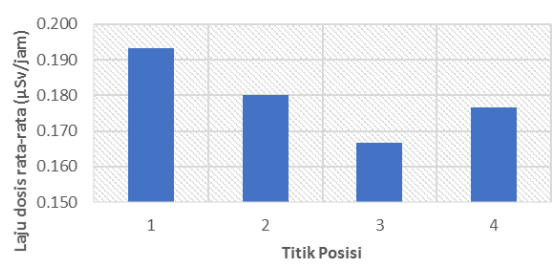

(c)

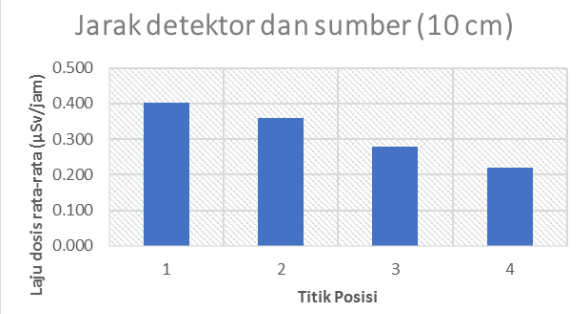

(e)
Jarak detektor dan sumber $(40 \mathrm{~cm})$

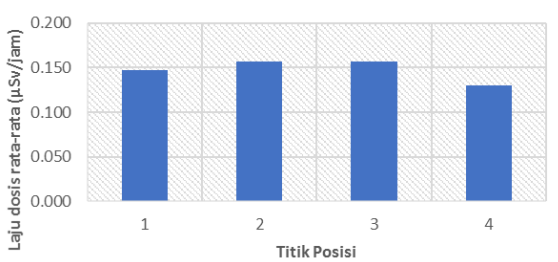

(b)

Jarak detektor dan sumber $(20 \mathrm{~cm})$

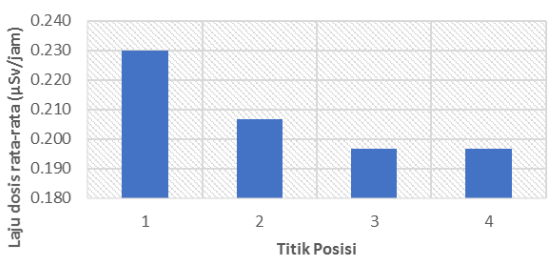

(d)

Jarak detektor dan sumber $(0 \mathrm{~cm})$

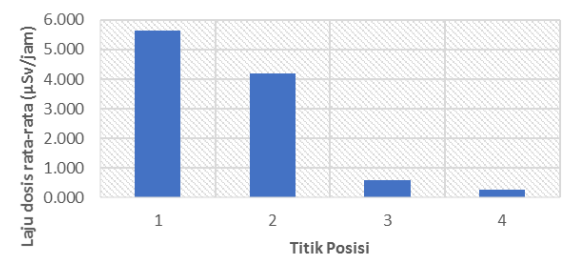

(f) 
Figure 5. Dose Rate Measurement in Source-to-Detector (STD) Distance of $50 \mathrm{~cm}$ (a), $40 \mathrm{~cm} \mathrm{(b),} 30 \mathrm{~cm}$ (c), $20 \mathrm{~cm}(\mathrm{~d}), 10 \mathrm{~cm}$ (e) and $0 \mathrm{~cm}(\mathrm{f})$

Dose rate measurement in STD distance of $50 \mathrm{~cm}$ and $40 \mathrm{~cm}$ does not show significance difference with the dose rate under $0.150 \mu \mathrm{Sv} / \mathrm{h}$ almost similar in every measurement position. Dose rate measurement in STD distance of $30 \mathrm{~cm}$, $20 \mathrm{~cm}$ and $10 \mathrm{~cm}$ show visible difference that provide the understanding of detector window position as is in position 1. Dose rate measurement in STD distance of 0 $\mathrm{cm}$ indicates that the radiation almost not detected in position 3 and 4 that shows ineffective radiation dose rate measurement in those position. The dose rate measurement done with STD distance $0 \mathrm{~cm}$ also show that position 1

and 2 detect the dose effectively resulting in the dose rate above 4.000 $\mu \mathrm{Sv} / \mathrm{h}$. The difference of dose rate measurement between position 1 and 2 with STD distance of $0 \mathrm{~cm}$ is $1.433 \mu \mathrm{Sv} / \mathrm{h}$ or counted to $25.74 \%$. The result show that detector position of GAM unit is very crucial to provide the actual dose rate in the temporary solid radioactive waste storage room area. The difference in dose rate measurement accounted to $25.74 \%$ of the dose rate is important to be considered in setting the threshold for radiation alarm. The dose rate measured by GAM detector will be accounted only to $74.26 \%$ of the actual dose if the detector is placed upwards, this number is acquired using the difference in dose rate measurement of $25.74 \%$. The characteristic of GAM detector proven by this data should give credible information for radiation safety officer to determine the direction of GAM detector and the threshold of radiation alarm

\section{CONCLUSION}

The result of dose rate measurement using in situ GAM Detector in 4 position gives information about the characteristic of the detector, which the radiation measurement by the detector will be most effective if done in the middle-front of the detector (position 1). The difference between measurement in position 1 and position 2 with STD distance of $0 \mathrm{~cm}$ using $1 \mu \mathrm{Ci}$ (base activity in 2011) Cs-137 source is $25.74 \%$ of total dose rate measured. Detector position, detector holder design, and alarm threshold setting should be evaluated to provide actual dose rate measured and improve radiation safety performance for worker in the temporary solid radioactive waste storage room.

\section{BIBLIOGRAPHY}

[1] R. Indonesia, "Undang-Undang Republik Indonesia," 1997.

[2] R. Indonesia, Peraturan Pemerintah Republik Indonesia Nomor 61 Tahun 2013 Tentang Pengelolaan Limbah Radioaktif, vol. 1, no. 1. 2013, pp. 69-73.

[3] Sjafruddin, "Keselamatan Radiasi Penanganan Limbah Radioaktif Radiasi Tinggi Dari Hotcell IRM," pp. 37-50, 2018.

[4] C. Li et al., "Managing internal radiation contamination following an emergency: Identification of gaps and priorities," Radiat. Prot. Dosimetry, vol. 171, no. 1, pp. 7884, 2016. 
[5] H. Scherthan, N. Sotnik, M. Peper, G. Schrock, T. Azizova, and M. Abend, "Telomere Length in Aged Mayak PA Nuclear Workers Chronically Exposed to Internal Alpha and External Gamma Radiation," Radiat. Res., vol. 185, no. 6, pp. 658-667, 2016.

[6] D. M. et Al, "Monte-Carlo simulation of beta particle induced bremsstrahlung doses," Certain distance degree based Topol. indices Zeolite LTA Fram., no. December 2016, pp. 11-14, 2018.

[7] C. Degueldre, J. Bertsch, and M. Martin, "Progress in Nuclear Energy Post irradiation examination of nuclear fuel: Toward a complete analysis," Prog. Nucl. Energy, vol. 92, pp. 242-253, 2016.

[8] S. Kuntjoro, P. M. Udiyani, and M. Budi Setiawan, "Fuel Burn-up and
Radioactivity Inventory Analysis for New In-core Fuel Management of the RSG-GAS Research Reactor," J. Phys. Conf. Ser., vol. 1198, no. 2, 2019.

[9] I. Akkurt, H. O. Tekin, and A. Mesbahi, "Calculation of Detection Efficiency for the Gamma Detector using MCNPX," Acta Phys. Pol. A, vol. 128, no. 2, pp. 332-334, 2015.

[10] H. Candra, Pujadi, and G. Wurdiyanto, "Pengaruh Efek Geometri pada Kalibrasi Efisiensi Detektor Semikonduktor HPGe Menggunakan Spektrometer Gamma," Pros. Pertem. IIm. XXIV HFI, no. April, pp. 258-264, 2010.

[11] S. Rosidi, Muljono, Sihono, “Uji Fungsi Detektor HPGE GEM-35p4 ORTEC Spektrometer Gamma Lab. AAN Tank-BKTPB," No. September, 2012. 